\title{
Reflections of Turkish accounting and financial reporting standards on vocational school students: A research on comparing perceptions of intermediate and mid-level accounting professional candidates
}

\author{
Hakan Seldüz ${ }^{1 \mathrm{a}}$, and Emine Seldüz ${ }^{2}$ \\ ${ }^{1}$ Vocational School of Social Sciences, Aksaray University, Aksaray 68100, Turkey \\ ${ }^{2}$ Institute of Social Sciences, Aksaray University, Aksaray 68100, Turkey
}

\begin{abstract}
This research aims to compare the perceptions of intermediate and mid-level accounting professional candidates on accounting and financial reporting standards. A significant part of accounting process is carried out by vocational school graduate intermediate and mid-level accounting professionals. However, it can be claimed that adequate education about accounting and financial reporting standards isn't given in vocational schools although these standards structure the whole accounting process. A survey is conducted over students of the related vocational school in Aksaray University. The results indicate no significant difference on students' perceptions in terms of their school year, high school type, job or internship experience and intention to perform the profession after graduation. These results can be traced to inadequacy of present curriculums and internship programs which can't create a difference. Based on the results, the content of internship applications is rearranged and an optional subject named as "Accounting and Reporting Standards" is established.
\end{abstract}

Keywords: Vocational schools; accounting education; accounting standards; financial reporting standards.

\section{Introduction}

Accounting practices are performed in accordance with regulations, generally accepted accounting principles, basic accounting concepts and national standards harmonized with internationally recognized sets. The new Turkish Commercial Code (TCC) issued in early 2011 requires mandatory implementation of Turkish Accounting Standards (TMS) and Turkish Financial Reporting Standards (TFRS) from mid 2012 which are fully compatible

${ }^{\text {a }}$ Corresponding author: selduz@hotmail.com

(C) The Authors, published by EDP Sciences. This is an open access article distributed under the terms of the Creative Commons Attribution License 4.0 (http://creativecommons.org/licenses/by/4.0/). 
with International Accounting Standards (IAS) and International Financial Reporting Standards (IFRS).

A significant part of accounting process in companies is carried out by intermediate and mid-level accounting professionals. Moreover, many are employed by independent certificated public accountant (CPA) offices as accounting clerks. Thus, vocational schools are important as they are the key resource of these professionals.

Most of public and private universities in Turkey provide a two-year accounting education by vocational school programs named as "Accounting" or "Accounting and Taxation Applications". When their curriculums and syllabuses are considered closely, it is seen that there are many compulsory and optional subjects including enough information about regulations, generally accepted accounting principles, basic accounting concepts and accounting applications. However it can be claimed that there are either no or just a little and superficial information is given in those courses about accounting and reporting standards which actually shape and structure the whole accounting procedures, processes and daily practices. This is identified as a shortcoming in vocational schools' related programs and it can be suggested that this shortcoming affects the students' perception on accounting and financial reporting standards; their contents, importance and necessity. Therefore, perceptions of intermediate and mid-level accounting professional candidates on accounting and financial reporting standards are chosen as the subject of this study.

\section{Accounting and financial reporting standards on international and national basis}

Leading professional associations which have been guiding international accounting practices are Financial Accounting Standards Board (FASB) and International Accounting Standards Board (IASB). IASB's principle-based standards characterize accounting practices' core while FASB's rule-based Generally Accepted Accounting Standards (USGAAP) define codes and modes of applications for transactions. US-GAAP has been adopted by many countries and thought to be adequate as an accounting standards whole because of its compatibility to conditions of free market economy and its high value of perceived reliability. Hence, US-GAAP adopters weren't interested in international standards developing efforts at first but financial scandals raised doubts about its adequacy. The belief of principle-based standards being more compatible than rule-based sets for global conditions got stronger. These changed US-GAAP adopters' attitude and support towards international efforts $[18,20,14]$. In 2001 IAS and in 2003 IFRS are issued as a result of these efforts [9].

In 2000, Basel Committee declared support on IAS/IFRS content and implementation while International Organization of Securities Commissions (IOSCO) and European Union (EU) predetermined implementation from 2005. Securities and Exchange Commission's (SEC) recommendation had influence over the support decisions of USA, UK, Canada, Australia and New Zealand in 2001. In 2002, IASB and FASB compromised on eliminating differences and incompatibilities with Norwalk Agreement; International Federation of Accountants (IFAC) accepted IAS; the need for single standards set is emphasized at 16th World Congress of Accountants and EU Parliament legislated member countries to act according to IAS/IFRS from 2005. By the end of 2006 IAS/IFRS had been obligatory in 69, proposed to oblige in 5, given permission for voluntary implementation in 21 and forbidden in 36 countries in the world $[2,1,18,17,20,3,6,7,8]$

Public Oversight-Accounting and Auditing Standards Authority (KGK), the authorized organization to set and issue accounting and financial reporting standards in Turkey, supported the global convergence process by issuing TMS/TFRS in 2002. Capital Markets Board of Turkey (SPK) prepared IFRS compatible standards and obliged for public 
companies from 2005. In 2006, Banking Regulation and Supervision Agency (BDDK) obliged TFRS implementation for banking sector [12, 4, 15, 10, 19]. TCC has been updated in 2011 according to these improvements and TMS/TFRS are legislated since 2012.

\section{Literature review}

There are a good number of studies focusing on the need of TMS/TFRS knowledge in accounting education in Turkey. Dalğar et al. [5] determine that the awareness of vocational school students about TMS/TFRS isn't at a desired level and is affected from students' personal interests and future career plans; but not from their educational background and previous work experiences. They suggest that establishing specific courses about TMS/TFRS could be useful in order to contribute increasing awareness levels of students by educational aspects and help them to be able to implement standards more easily in their future careers. Kurnaz [13] asserts that TMS/TFRS awareness of students who have previous accounting profession experience, intend to practice the profession in future and have more interest in accounting area is higher than others. Y1ldız and Yanık [22] state that students' intention to practice the profession indicates a linear relationship with their TMS/TFRS perceptions while factors of vocational interest, internship or work experience and high school type don't; and propound establishing compulsory subjects to enhance their knowledge and perception levels. Yanık and Yıldız [21] point out that both vocational school and faculty students' general TMS/TFRS perceptions are not at a desired level and propose to settle related courses. Their findings demonstrate that there is no difference between the perceptions of vocational school and faculty students who have intention to practice the profession in the future and who are interested in accounting profession. Karakaya Demirkutlu [11] repeats the same result; low general perception levels about TMS/TFRS of students and the linear relationship between their perceptions and interests in accounting area. Tugay and Ömürbek [16] lay stress on the importance of accounting standards and remark the need of updating accounting programs' curriculums accordingly in their research aiming to detect utilization and sufficiency levels of shop classes in accounting profession.

\section{Research method}

The problem of this research is set as "Do intermediate and mid-level accounting professional candidates' perceptions on accounting and financial reporting standards differ in terms of school year, high school type, job or internship experience and intention to perform the profession after graduation; or not?" In accordance with the problem, the main objective is to compare vocational school students' perceptions in terms of school year, high school type, job or internship experience and intention to perform the profession after graduation.

The research is limited with the students of Accounting and Taxation Applications in Aksaray University Vocational School of Social Sciences. A simple random sample group of 129 respondents is formed to represent a total population of 151 students which is shown in Table 1. Sample size represents \% 83 of the registered students in 2014-2015 Spring Semester. The research is conducted over students by a two-part survey adapted from Dalğar et al [5] and Karakaya Demirkutlu [11]. The first part provides demographic and descriptive information about participants while the second part contains the questionnaire form arranged with five point Likert type items to measure the perceptions. The gathered data is analyzed by using IBM SPSS 15.0 statistical data analysis software. 
Table 1.Registered students of related program in 2014-2015 education year.

\begin{tabular}{llll}
\hline School year & Formal education & Evening education & Total \\
\hline Junior class & 36 & 34 & 70 \\
Senior class & 42 & 39 & 81 \\
\hline Total & 78 & 73 & 151 \\
\hline
\end{tabular}

\section{Findings}

Some descriptive factors, which shaped the hypotheses, are obtained among demographic information. These are summarized in Table 2. Table 3 demonstrates mean and standard deviation values of students' perceptions on TMS/TFRS. Reliability statistics of the scale containing 18 items to measure students' perceptions is tested and Cronbach's Alpha value for internal consistency is calculated as 0,840 which is higher than the minimum acceptable value 0,70 . The obtained data sets displayed non-parametric distribution and were not suitable for parametric test techniques. For this reason, the research hypotheses are measured with Mann-Whitney $U$ test to explain the levels of significance because independent sample $t$ test couldn't be applied. The research hypotheses are listed below:

H1: TMS/TFRS perceptions of senior class students are significantly different from junior class students.

H2: TMS/TFRS perceptions of students who are commercial high-school graduates are significantly different from perceptions of students who are graduated from other type of high schools.

H3: TMS/TFRS perceptions of students who have a previous job or internship experience in accounting area are significantly different from students who don't.

H4: TMS/TFRS perceptions of students who intend to perform the profession after graduation are significantly different from students who don't.

Table 2. Descriptive information about respondents.

\begin{tabular}{lll}
\hline Descriptive information & Frequency & Val. percent \\
\hline School year & & \\
$\quad$ Junior & 69 & 53,5 \\
$\quad$ Senior & 60 & 46,5 \\
High School Type & 49 & 38,0 \\
$\quad$ Commercial & 80 & 62,0 \\
Other & 72 & 55,8 \\
Previous job/internship experience & 57 & 44,2 \\
Yes & & \\
No & 95 & 73,6 \\
Intention to perform the profession after graduation & 34 & 26,4 \\
Yes & 129 & 100,0 \\
No & & \\
Total
\end{tabular}


Table 3. Mean and standard deviation values of students' perceptions on TMS/TFRS.

\begin{tabular}{lllllllll}
\hline Statement & Mean & Std. Dev. & Statement & Mean & Std. Dev. & Statement & Mean & Std. Dev. \\
\hline S1 & 3,60 & 1,215 & S7 & 3,10 & 1,022 & S13 & 3,48 &, 936 \\
S2 & 3,55 &, 968 & S8 & 3,24 & 1,158 & S14 & 3,39 &, 955 \\
S3 & 3,18 & 1,027 & S9 & 3,36 &, 847 & S15 & 3,42 &, 916 \\
S4 & 3,39 &, 913 & S10 & 3,50 &, 977 & S16 & 3,37 &, 848 \\
S5 & 3,26 &, 869 & S11 & 3,22 & 1,062 & S17 & 2,98 & 1,118 \\
S6 & 2,97 & 1,007 & S12 & 3,47 & 1,024 & S18 & 3,23 & 1,064 \\
\hline
\end{tabular}

H1 aims to measure the difference between perceptions of junior and senior class students on TMS/TFRS. It is tested with Mann-Whitney $U$ test because a normal distribution wasn't observed. The results are shown in Table 4. According to MannWhitney $\mathrm{U}$ test results, $\mathrm{H} 1$ is refused because the table value is $0,819>0,05$ at significance level of 0,05 . This result shows that there is no significant difference between the perceptions of senior and junior class students on TMS/TFRS. This might mean that more than 3 semesters of accounting education couldn't create a difference on students' perceptions about TMS/TFRS and can be explained by shortcomings of current curriculums.

Table 4. Mann-Whitney $U$ test of the relation between school year and perception.

\begin{tabular}{llllll}
\hline $\begin{array}{l}\text { School } \\
\text { year }\end{array}$ & $\mathrm{N}$ & $\begin{array}{l}\text { Mean } \\
\text { Rank }\end{array}$ & $\begin{array}{l}\text { Sum of } \\
\text { Ranks }\end{array}$ & $\begin{array}{l}\text { TMS/TFRS Perception } \\
\text { Levels Mean }\end{array}$ \\
\hline Junior & 69 & 64,30 & 4436,50 & Mann-Whitney U & 2021,500 \\
Senior & 60 & 65,81 & 3948,50 & Wilcoxon W & 4436,500 \\
Total & 129 & & & Z &,- 229 \\
& & & & Asymp. Sig. (2-tailed) &, 819 \\
\hline
\end{tabular}

$\mathrm{H} 2$ is formed in order to define the difference between the perceptions of commercial high school graduates and other type of high school graduates on TMS/TFRS. Table 5 demonstrates the results of Mann-Whitney $U$ test applied on $\mathrm{H} 2$ because there was not a normal distribution. As the observed table value is $0,350>0,05$ at 0,05 significance level, $\mathrm{H} 2$ is refused. The result indicates that there is no significant difference between the perceptions of students graduated from commercial high schools and other type of high schools. According to this result, it can be claimed that students' previous educational backgrounds doesn't play a crucial a role in their perceptions about TMS/TFRS.

Table 5. Mann-Whitney $U$ test of the relation between high school type and perception.

\begin{tabular}{llllll}
\hline $\begin{array}{l}\text { High school } \\
\text { type }\end{array}$ & $\mathrm{N}$ & $\begin{array}{l}\text { Mean } \\
\text { Rank }\end{array}$ & $\begin{array}{l}\text { Sum of } \\
\text { Ranks }\end{array}$ & $\begin{array}{l}\text { TMS/TFRS Perception } \\
\text { Levels Mean }\end{array}$ \\
\hline Commercial & 49 & 68,93 & 3377,50 & Mann-Whitney U & 1767,500 \\
Other & 80 & 62,59 & 5007,50 & Wilcoxon W & 5007,500 \\
Total & 129 & & & $\mathrm{Z}$ &,- 935 \\
& & & & Asymp. Sig. (2-tailed) &, 350 \\
\end{tabular}


In order to identify the difference in perceptions of students on TMS/TFRS according to their previous job or internship experiences H3 is formed. Again there was not a normal distribution observed so Mann-Whitney $U$ test is performed. Table 6 summarizes the results. $\mathrm{H} 3$ is refused because the table value is $0,335>0,05$ at 0,05 significance level. It can be stated that students' previous job or internship experiences didn't add a value onto their perceptions on TMS/TFRS. This can be attributed to low levels of knowledge and experience about TMS/TFRS in trade and business environment because of obligatory applications' relatively being new.

Table 6. Mann-Whitney $U$ test of the relation between job or internship experience and perception.

\begin{tabular}{llllll}
\hline $\begin{array}{l}\text { Job or internship } \\
\text { experience }\end{array}$ & $\mathrm{N}$ & $\begin{array}{l}\text { Mean } \\
\text { Rank }\end{array}$ & $\begin{array}{l}\text { Sum of } \\
\text { Ranks }\end{array}$ & $\begin{array}{l}\text { TMS/TFRS Perception } \\
\text { Levels Mean }\end{array}$ \\
\hline Yes & 72 & 67,82 & 4883,00 & Mann-Whitney U & 1849,000 \\
No & 57 & 61,44 & 3502,00 & Wilcoxon W & 3502,000 \\
Total & 129 & & & $\mathrm{Z}$ &,- 964 \\
& & & & Asymp. Sig. (2-tailed) &, 335 \\
\hline
\end{tabular}

H4 compares TMS/TFRS perceptions of the students who intend to perform the profession after graduation and the students who don't. Mann-Whitney U test is performed to test $\mathrm{H} 4$ due to lack of normal distribution and the results are given with Table 7 . H4 is refused because the observed table value $0,270>0,05$ at 0,05 significance level. This result can be interpreted with both student groups' low knowledge and awareness levels about importance and contents of TMS/TFRS in no regard to their intentions to perform the profession after graduation.

Table 7. Mann-Whitney $U$ test of the relation between intention to perform the profession and perception.

\begin{tabular}{lcclll}
\hline $\begin{array}{l}\text { Intention to perform } \\
\text { the profession }\end{array}$ & $\mathrm{N}$ & $\begin{array}{l}\text { Mean } \\
\text { Rank }\end{array}$ & $\begin{array}{l}\text { Sum of } \\
\text { Ranks }\end{array}$ & $\begin{array}{l}\text { TMS/TFRS Perception } \\
\text { Levels Mean }\end{array}$ \\
\hline Yes & 95 & 67,17 & 6381,00 & Mann-Whitney U & 1409,000 \\
No & 34 & 58,94 & 2004,00 & Wilcoxon W & 2004,000 \\
Total & 129 & & & Z & $-1,102$ \\
& & & & Asymp. Sig. (2-tailed) &, 270 \\
\hline
\end{tabular}

\section{Conclusion}

The results do not indicate any significant differences on students' perceptions about TMS/TFRS in terms of their school year, high school type, job or internship experience and intention to perform the profession after graduation. These results can be explained with inadequacy of students' knowledge and awareness levels about contents, importance and necessity of TMS/TFRS which arises from concerned vocational school program's present curriculums and contains of internship applications. It can be said that TMS/TFRS are just briefly and superficially mentioned in some courses but not in an independent and directly related course. It is observed that issues about TMS/TFRS are almost completely disregarded during internship applications which merely focus on traditional simple bookkeeping transactions. 
Based on this study's results, it is proposed to Aksaray University presidency to establish an optional subject named as "Accounting and Reporting Standards" for the senior year's spring semester of Accounting and Taxation Applications Program in Vocational School of Social Sciences. The presidency accepted the proposal and the subject will be included into the curriculum from 2015-2016 education year. The content of internship applications is also reviewed and updated according to the determined issues. These might help to increase students' knowledge and awareness levels on contents, importance and necessity of TMS/TFRS and create significant differences in the future in terms of school year, high school type, job or internship experience and intention to perform the profession.

This research includes only the relevant program of Vocational School of Social Sciences in Aksaray University. It can be suggested for future studies to expand the research area to students of other vocational schools of public and private universities and also for business administration departments of related faculties.

\section{References}

1. Aksoy, T., Finansal muhasebe ve raporlama standartlarında uyumlaştırma ve UMS/UFRS bazında küresel muhasebe standartları setine yöneliş eğilimi, Mali Çözüm, 71, 182-199, (2005).

2. Aslan, S., Uluslararası finansal raporlama standartları ile getirilen yeni düzenlemeler: IFRS1-5, Muhasebe ve Denetime Bakış, 13, 45-61, (2004).

3. Aysan, M.A., Muhasebe ve kurumsal yönetim, Muhasebe ve Finansman Dergisi, 35, 17-24, (2007).

4. Bekçi, İ., Muhasebe meslek mensuplarının türkiye muhasebe standartları hakkındaki görüşlerinin değerlendirilmesine yönelik bir araştırma, Muhasebe ve Denetime Bakış, 22, 27-40, (2007).

5. Dalğar, H., Çelik, İ. \& Mortaş, M., Muhasebe öğrenimi gören öğrencilerin TMS/TFRS hakkındaki farkındalıklarına yönelik bir araştırma, Süleyman Demirel Üniversitesi İ̈BF Dergisi, 16 (1), 217-230, (2011).

6. Deloitte, IAS Plus, http://www.iasplus.com/en/publications/global/ifrs-in-yourpocket/pub1606, Access date: 04.20.2014, (2008).

7. Demir, V., Finansal raporlama uygulamalarına ilişkin farklı yaklaşımlar, Muhasebe ve Denetime Bakış, 29, 73-92, (2009).

8. Durak, M.G. \& Balsarı, Ç.K., Türkiye'de UFRS araştırmalarına genel bakış, Dayanışma, 113, 9-24, (2011).

9. IFRS, Standards, http://www.ifrs.org/IFRSs/Pages/IFRS.aspx, Access date: 03.26.2014, (2014).

10. Karacan, S. \& Güngör, A., Uluslararası muhasebe-finansal raporlama standartları (UMS/UFRS) ile ilgili yapılan çalışmalar, Kocaeli Bülteni, Kocaeli Serbest Muhasebeci Mali Müşavirler Odası(KSMMMO) Yayın Organı, 13 (41), 1-8, (2008).

11. Karakaya Demirkutlu, F.K., İşletme lisans öğrencilerinin Türkiye muhasebe/finansal raporlama standartları hakkındaki ilgi düzeyleri, beklentileri ve farkındalıkları: Gazi Üniversitesi Iktisadi ve Idari Bilimler Fakültesi örneği, Gazi Üniversitesi İIBB Dergisi 16 (2), 156-174, (2014).

12. Kayacan, M., Kurumsal yönetim ilkeleri ve ulusal finansal raporlama standartları açısından gelişmeler, İzmir Serbest Muhasebeci Mali Müşavirler Odası 10. Türkiye Muhasebe Standartları Sempozyumu, 6-10 Aralık 2006, Girne/Kıbris, 61-84, (2006).

13. Kurnaz, N., Statistical analysis of the factors affecting accounting students' awareness of the TAS (Turkish Accounting Standards) and TFRS (Turkish Financial Reporting Standards), British Journal of Science, 4, 142-56 (2012). 
14. Poroy Arsoy, A., Kurumsal şeffaflık ve muhasebe standartları, Afyon Kocatepe Üniversitesi İ̈BF Dergisi, 10 (2), 17-35, (2008).

15. Şahin, D. \& Pazarçeviren, S.Y., "TFRS (TMS 1, TMS 2, TMS 7, TMS 18, TMS 24, TMS 40) ve SPK muhasebe standartlarının IRFS ile karşılaştırılması, Akademik İncelemeler, 2 (2), 129-146, (2007).

16. Tugay, O. \& Ömürbek, V., Meslek yüksekokullarında verilen muhasebe derslerinin uygulamada kullanılma düzeyi ve yeterliliği üzerine bir araştırma, Niğde Üniversitesi İ̈BF Dergisi, 7 (3), 53-74, (2014).

17. Türker, M., Uluslararası denetim standartlarına yakınsama ve Türkiye denetim standartlarının oluşturulması, Muhasebe ve Denetime Bakış, 19, 87-98, (2006).

18. Ulusan, H., Menkul kıymet borsalarına kayıtlı şirketlerde IAS/IFRS'nin kabulü veya IAS/IFRS'ye uyum, Muhasebe ve Denetime Bakış, 15, 9-30, (2005).

19. Uyar, A. \& Güngörmüş, A. H., Perceptions and knowledge of accounting professionals on IFRS for SMEs: Evidence from Turkey. Research in Accounting Regulation, 25(1), 77-87, (2013).

20. Uysal, Ö.Ö., Uluslararası muhasebe standartlarının oluşum süreci: ISAC ve önde gelen ulusal ve uluslararası örgütler, Muhasebe ve Denetime Bakış, 17, 87-107, (2006).

21. Yanık, A. \& Yıldız, F., Lisans ve önlisans düzeyinde öğrenim gören öğrencilerin muhasebe standartları hakkındaki algılarının karşılaştırılması: Bir araştırma, Süleyman Demirel Üniversitesi İ̈BF Dergisi, 18 (2), 443-458, (2013).

22. Yıldız, F. \& Yanık, A., Yükseköğretimde öğrenim gören öğrencilerin muhasebe ve finansal raporlama standartları hakkındaki algıları: Ampirik çalışma, Süleyman Demirel Üniversitesi SBE Dergisi, 1 (17), 205-220, (2013). 